\title{
ESTIMATES OF THE DOSE OF RADON AND ITS PROGENY INHALED INSIDE BUILDINGS
}

\author{
PURUSHOTHAMA RAVIKUMAR* \\ and RAYASAMUDRA KALEGOWDA SOMASHEKAR
}

Department of Environmental Science, Bangalore University, Bangalore, India - 560056

*Corresponding author: prakruthiravi@gmail.com, nisargaravi@gmail.com

\begin{abstract}
The concentration of radon in the air in buildings ranged from $1.87 \pm 3.24 \mathrm{~Bq} / \mathrm{m}^{3}$ to $14.27 \pm 1.50 \mathrm{~Bq} / \mathrm{m}^{3}$ with a mean of $6.31 \pm 3.47 \mathrm{~Bq} / \mathrm{m}^{3}$ while that of the progeny of radon varied from 0.007 to $0.057 \mathrm{WL}$ (average: 0.025 ). The mean indoor concentration of radon was considerably less than the lower levels prescribed by EPA $\left(148 \mathrm{~Bq} / \mathrm{m}^{3}\right)$, WHO $\left(100 \mathrm{~Bq} / \mathrm{m}^{3}\right), \mathrm{EEC}\left(400 \mathrm{~Bq} / \mathrm{m}^{3}\right), \operatorname{ICRP}\left(200-600 \mathrm{~Bq} / \mathrm{m}^{3}\right)$ and NRPB $\left(200 \mathrm{~Bq} / \mathrm{m}^{3}\right)$. The annual effective equivalent dose of indoor radon $(<0.8 \mathrm{mSv} / \mathrm{y})$ that the bronchial and pulmonary regions of human lungs are exposed to $(<0.8 \mathrm{mSv} / \mathrm{y})$ is less than the UNSCEAR and WHO recommended global lower average dose value of $1 \mathrm{mSv} / \mathrm{y}$. The lifetime fatality risk of exposure to the progeny of radon (PAEC) varied from $0.03 \times 10^{-4}$ to $0.19 \times 10^{-4}$, with an average value of $0.08 \pm 0.04 \times 10^{-4}$.
\end{abstract}

Keywords: radon, indoor, equilibrium-equivalent radon concentration, equivalent dose, lifetime fatality risk

\section{Introduction}

The noble radioactive gas radon tends to migrate readily in air or water in spite of the fact that its relatively short half-life (3.82 days) restricts the time for which it can migrate (Choubey and Ramola 1997). The presence of radon in soil, water and rock has greatly facilitated our ability to identify and predict the occurrence of earthquakes, volcanic activity and fault dislocation. Coincidently, its presence at high levels in indoor air could be a health hazard for humans because it is carcinogenic (Karimdoust and Ardebili 2010) and can cause lung cancer (Folger et al. 1994). Radon and its short-lived decay products $\left({ }^{218} \mathrm{Po},{ }^{214} \mathrm{Po}\right.$ and ${ }^{214} \mathrm{Bi}$ etc.) in buildings is the major source of public exposure to natural radioactivity, making up almost $50 \%$ of the worldwide mean effective dose (UNSCEAR 2000b; Somlai et al. 2007). Two of the a-emitting daughters of ${ }^{222} \mathrm{Rn}\left({ }^{218} \mathrm{Po}\right.$ and $\left.{ }^{214} \mathrm{Po}\right)$ contribute over $90 \%$ of the total radiation dose attributable to exposure to radon (Gillmore et al. 2001). When radon decays after inhalation or ingestion, it releases energy that can damage DNA in the cells of sensitive organs like lungs and stomach and can cause cancer. Thus, naturally occurring radon in buildings has been identified as a human lung carcinogen (IARC 1988; WHO 2009) and is considered to be the second leading cause of lung cancer after smoking tobacco (Marley et al. 1998; WHO 2005). Recent studies have also provided information on the risks of exposure to lower levels of radon (Lubin and Boice 1997; NRC 1999; EPA 2004). Further, ICRP (1990) recommends that exposure to high levels of radon should be considered to be an occupational hazard and remedial actions need to be initiated in such situations. In recent years, substantial attention has been paid to radon, particularly the problems of exposure to radon and its progeny in building and dwellings. Measurements of levels of radon in the air in dwellings worldwide have been made and reported (Srivastava 2004; Oufnia et al. 2005; Pauloa et al. 2005). In the open air the concentration of radon gas is very low and does not pose a significant health hazard. However, radon is a problem when released into an enclosed or poorly ventilated spaces like dwellings, buildings, caves and mines, where this gas can accumulate and reach relatively high concentrations and become a health hazard. Emanation and migration of radon and its progenies in an indoor environment (in the earth and atmosphere) has been identified as the main source of the radiation from natural radioactive sources that people are exposed to. Indoor concentrations of radon and its short-lived progeny depend mainly on the entry or production rate from various sources and the ventilation rate. However, the level of radon in an indoor environment can also depend on the nature of building materials, soil, water used for drinking and other domestic features (Sohrabi 1998).

Thus, in the present investigations, a RAD7 radon analyzer system was used to study variation in the level of radon in the staff room of the Department of Environmental Science, Bangalore University, Bangalore. The annual effective dose of radon inhaled by the inhabitants was also calculated in order to determine their exposure dosage to radiation.

\section{Material and methods}

RAD7 analyzer is an active, high performance, continuous radon-measuring technique (Fig. 1), which is extensively used because it is rugged and simple to use, produces a long-term integrated read out and is highly 
sensitive to alpha-particle radiation. In the present study, the surface deposited/airborne/ambient radon activity inside the staff room was recorded by the RAD7 radon analyzer using a continuous 1-day protocol. Grab sampling may not give an accurate value of the radon levels because radon concentrations change significantly and rapidly. The RAD7 detector collects the $\alpha$-emitters electrostatically and analyses them spectrally.

Ambient air is sucked in by a pump at a rate of $11 / \mathrm{min}$, and passes through a drierite/desiccant and filter prior to entering the solid-state detector, which measures the concentration of radon. The RAD7 determines the concentration of radon in air by detecting the alpha decaying radon progeny, ${ }^{218} \mathrm{Po}$ and ${ }^{214} \mathrm{Po}$, using a solid-state, passivated ion-implanted planar silicon (PIPS) detector. The radon monitor (RAD7) uses a high electric field above a silicon semi-conductor to attract the positively charged polonium daughters, ${ }^{218} \mathrm{Po}^{+}(\mathrm{t} 1 / 2=3.1 \mathrm{~min}$; alpha energy $=6.00 \mathrm{meV})$ and ${ }^{214} \mathrm{Po}^{+}(\mathrm{t} 1 / 2=164 \mathrm{ls}$; alpha energy $=7.67 \mathrm{meV})$, which are then used as a measure of the concentration of ${ }^{222} \mathrm{Rn}$ in the air. The concentration of radon was measured every hour for 1 day (24 hours), using the continuous monitoring mode. Finally, ${ }^{222} \mathrm{Rn}$ activities are expressed in terms of $\mathrm{Bq} / \mathrm{m}^{3}$ (disintegrations per second per $\mathrm{m}^{3}$ ) with $2 \sigma$-uncertainties. One Becquerel corresponds to one radioactive disintegration per second and Becquerels per cubic metre $\left(\mathrm{Bq} / \mathrm{m}^{3}\right)$ is the unit of expression used to define the concentration of radioactive gases, such as radon.

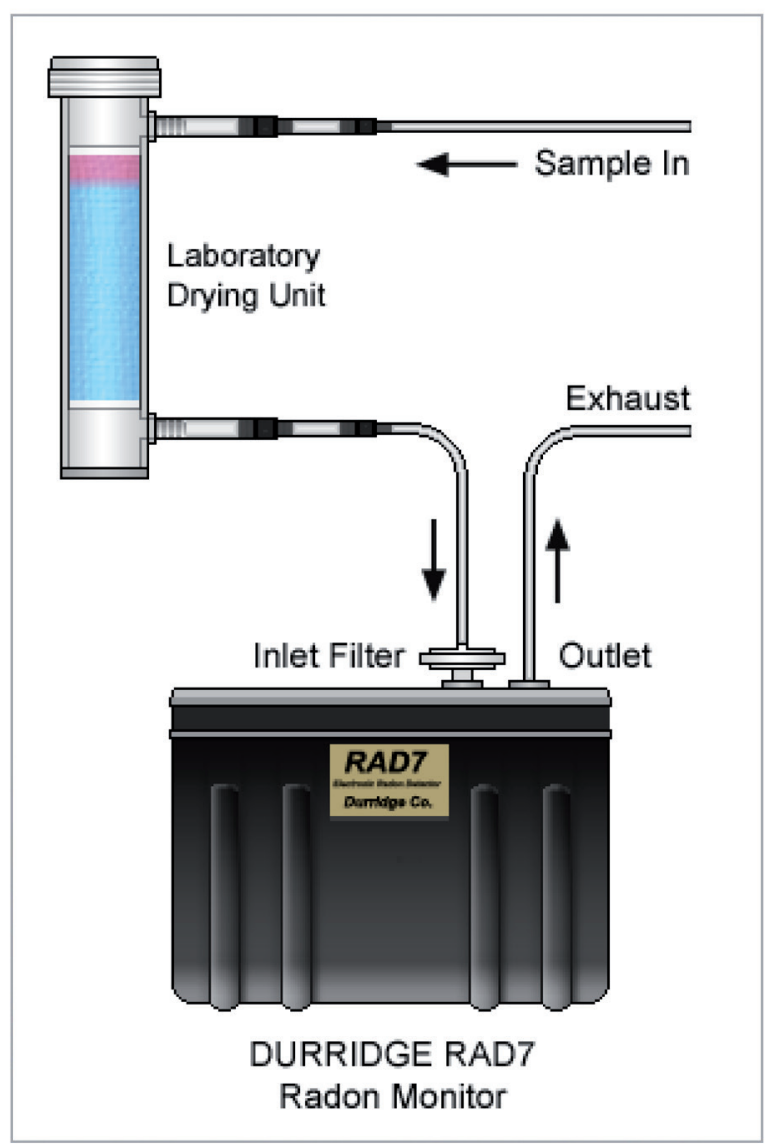

Fig. 1 Experimental set-up for the measurement of radon in air.
There is a desiccant drying tube, containing anhydrous $\mathrm{CaSO}_{4}$ at the interface between the ambient air and the detector, which maintains the relative humidity $(\mathrm{RH})$ of the incoming air below $10 \%$ throughout the measurement. If it goes above $10 \%$ then desiccant should be replaced, as the sensitivity of the particle detector is lowered significantly when the relative humidity is higher than $10 \%$. Inlet filters at the top of the RAD7 remove the progenies of ${ }^{220} \mathrm{Rn}$ and ${ }^{222} \mathrm{Rn}$, so that only the concentration of the gas is measured. The detector operates at external relative humidities ranging from $0 \%$ to $95 \%$ and an internal humidity of $0-10 \%$, with a sensitivity of $4 \mathrm{~Bq} / \mathrm{m}^{3}$ and an upper linear detection limit of $800 \mathrm{kBq} / \mathrm{m}^{3}$. In other words, the sensitivity of the instrument is 0.8 counts per hour per $\mathrm{Bq} / \mathrm{m}^{3}$ and 0.4 counts per hour per $\mathrm{Bq} / \mathrm{m}^{3}$ in normal and sniff modes, respectively. The dynamic range of the instrument is $4-400,000 \mathrm{~Bq} / \mathrm{m}^{3}$ (0.1-10,000 pCi/l).

\section{Action level for radon inhaled indoors}

If the concentration of radon goes above the "Action level" attempts should be made to reduce it because of its adverse effect on human health. In this context, the Environmental Protection Agency (EPA) report that if a person is exposed to an indoor radon level of 4 picocuries per litre $(4 \mathrm{pCi} / \mathrm{l})$ or 148 Becquerel per cubic meter $\left(148 \mathrm{~Bq} / \mathrm{m}^{3}\right)$, the probability of developing lung cancer is $13-50$ persons per 1000 . Furthermore, exposure to a radon level of $20 \mathrm{pCi} / \mathrm{L}\left(740 \mathrm{~Bq} / \mathrm{m}^{3}\right)$ is as hazardous as smoking a pack of cigarettes a day. Therefore, EPA recommends a rigid $4 \mathrm{pCi} / 1\left(=148 \mathrm{~Bq} / \mathrm{m}^{3}\right)$ as the action-level for air-borne radon and that a radon action level of lower than this should be maintained in the air in residences (EPA 1986). EPA recommends that it be reduced to a lower level if a home is at or above the threshold value. For conversion, multiply pCi/l (non-SI terminology) by 37 to get $\mathrm{Bq} / \mathrm{m}^{3}$ (SI terminology). WHO suggests that house owners take action when radon levels exceed $100 \mathrm{~Bq} / \mathrm{m}^{3}$, which is a much more conservative figure than the Environmental Protection Agency (EPA) action level of $148 \mathrm{~Bq} / \mathrm{m}^{3}$ (EPA 1991), which has been the USA standard for many years (WHO, 2009). Similarly, the Economic European Community (EEC) has prescribed a level of $400 \mathrm{~Bq} / \mathrm{m}^{3}$ for indoor radon in built dwellings, ICRP (International Commission on Radiological Protection) recommend a range of action levels for radon of 200-600 Bq/m³ (ICRP 1993b, 1994), NRPB (National Radiological Protection Board, U.K.) a threshold limit value of $200 \mathrm{~Bq} / \mathrm{m}^{3}$ for houses and $400 \mathrm{~Bq} / \mathrm{m}^{3}$ for workplaces (NRPB 1990) and the Irish reference level is $200 \mathrm{~Bq} / \mathrm{m}^{3}$ (ICRP 1993b).

\section{Radon dosimetry / Equivalent dose}

Although there are large uncertainties in assessing the dosimetry and epidemiological aspects for converting an exposure to radon to a radon dose (Chen 2005), it is nevertheless essential to be able to estimate the ra- 
don dose from the radon concentration because of its harmful effects on the human body. The equilibrium level, time spent indoors and the conversion coefficient (effective dose received by adults per unit ${ }^{222} \mathrm{Rn}$ activity per unit of air volume) of the recorded dose are the major factors determining the level of the dose (ed.) received by bronchial and pulmonary tissues of human lungs. Hence, in the present study we used six different methods to compute the annual effective equivalent dose or inhalation dose attributable to exposure to indoor radon using different radon dose conversion and equilibrium factors.

\section{Method 1:}

Concentrations of radon decay products or their equivalent equilibrium concentrations (EECs) can be obtained from radon data using calculation procedure of Kranrod et al., (2009). The concentration of radon recorded indoors $\left(A_{R n}\right)$ in $B q / \mathrm{m}^{3}$ can be expressed in terms of equilibrium-equivalent radon concentration $\left(\mathrm{EEC}_{\mathrm{Rn}}\right)$ by using relation (1) (Choubey and Ramola 1997) and the equivalent dose received by bronchial and pulmonary tissues in human lungs by using a dose conversion factor $(\mathrm{DCF})$ of $1.0 \times 10^{-5} \mathrm{mSv}$ per $\mathrm{Bqh} / \mathrm{m}^{3}$ (ICRP 1987; Choubey and Ramola 1997) and equilibrium factor (F) of 0.45 in equation (2):

$E E C_{R n}=F \times A_{R n}(1)$

Equivalent dose $=E E C_{R n} \times D C F$

\section{Method 2:}

Recommendations in the United Nations Scientific Committee's publication on the Effects of Atomic Radiation (UNSCEAR 2000b, 2006; Abd El-Zaher and Fahmi 2008; Abd El-Zaher 2011) can be used to calculate the annual effective dose from exposure to radon. The effective indoor dose $\left(\mathrm{H}_{\mathrm{E}}\right)$ was calculated using a conversion factor of $9.0 \mathrm{nSv} / \mathrm{h}$ per $\mathrm{Bq} / \mathrm{m}^{3}$ (UNSCEAR, 2000b), an indoor occupancy factor of 0.8 (Chen and Moir 2010) and an equilibrium factor of ${ }^{222} \mathrm{Rn}$ indoors of 0.4 in equation (3):

$H_{E}=C_{R n} \times F \times T \times D C F$

where

$H_{E}=$ effective indoor dose rate in $\mathrm{mSv} / \mathrm{y}$,

$C_{R n}=$ is the arithmetic mean radon concentration in $\mathrm{Bq} / \mathrm{m}^{3}$,

$F=0.4$ is the typical recommended equilibrium factor value used for indoor radon (ICRP 1993b, 1994; UNSCEAR 1999),

$T=$ Indoor occupancy time of $7000 \mathrm{~h}$ or $80 \%$ of office occupancy $(0.8 \times 24 \mathrm{~h} \times 365.25=7012.8 \mathrm{~h} / \mathrm{y})$.

$\mathrm{DCF}=$ a recommended value of $9 \mathrm{nSv}\left(\mathrm{Bqm}^{-3} \mathrm{~h}\right)^{-1}$ or $9 \mathrm{nSv} / \mathrm{Bqhm}^{-3}$ or $9.0 \times 10^{-6} \mathrm{mSv} / \mathrm{h}$ per $\mathrm{Bq} / \mathrm{m}^{3}$ was used to convert radon equilibrium-equivalent concentration to population effective dose (UNSCEAR 2000b; Chen and Moir 2010) as it lies between the dosimetric and epidemiological dose conversions (IARC 1988; UNSCEAR 2000b; WHO 2009).

\section{Method 3:}

Method 3 involved estimating the annual effective dose (Dy) due to a particular concentration of radon using equation (4) or (5) (Örgün et al. 2008; Ali Asghar Mowlavi et al. 2012):

$D y=E_{f} \times C_{f} \times O_{f} \times Q_{R n} \times T$

or

$E D(m S v / y)=A_{c} \times D_{f} \times O_{f} \times E_{f} \times 24 \mathrm{~h} \times 365 \times 10^{-6}$

where

$E_{f}=0.4$, indoor radon decay product equilibrium factor, $C_{f}$ or $D_{f}=9.0 \mathrm{nSv} / \mathrm{Bq} \mathrm{h} \mathrm{m}{ }^{-3}$, radon effective dose coefficient factor,

$O_{f}=0.8$, indoor occupancy factor, which is the fraction of the time people spend indoors - it means, during a year $(T=365 \times 24 \mathrm{~h})$ people spend about $7008 \mathrm{~h}$ indoors in homes and offices,

$Q_{R n}$ or $A_{C}=$ the radon concentration in $\mathrm{Bq} / \mathrm{m}^{3}$.

\section{Method 4:}

The effective equivalent dose due to exposure to indoor radon can be expressed in two different ways as indicated by equation (6) and (7) (Martinez et al. 1998). In addition, equation (6) in terms of the equilibrium factor (F) can also be expressed by equation (7) (Farid 1993, 1995):

$H_{E}=C_{R n} d_{0}+d_{1} C_{E}$

$H_{E}=C_{R n}\left(d_{0}+d_{1} F\right)$

where

$C_{E}$ is equivalent concentration of radon in $\mathrm{Bq} / \mathrm{m}^{3}$,

$F=0.4$, the typical value of the equilibrium factor used for indoor radon,

$d_{0}$ and $d_{1}=$ the effective dose equivalent conversion factors for radon and radon progeny, respectively.

The recommended values (Mauricio et al. 1985; WHO 1988; Planinic and Faj 1989, 1990; Faj and Planinic, 1991;)

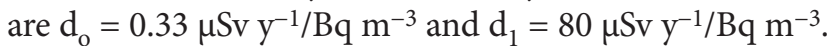
In the present study equation (7) was used.

\section{Method 5:}

The CEC (1990) recommends that a conversion ratio of $1 \mathrm{~Bq} / \mathrm{m}^{3}$ of ${ }^{222} \mathrm{Rn}$ corresponding to an effective equivalent dose of $0.05 \mathrm{mSv} / \mathrm{y}$ can be used to calculate the effective equivalent dose (Maged 2009).

\section{Method 6:}

It is possible to estimate the effective dose $(\mathrm{mSv} / \mathrm{y})$ due to the inhalation of radon and its progeny by using a conversion coefficient of $9 \mathrm{nSv} / \mathrm{Bq} \mathrm{h} \mathrm{m} \mathrm{m}^{-3}$, equilibrium factor of 0.6 , outdoor occupancy factor of $1760 \mathrm{~h}$ and a dose coefficient for radon dissolved in blood of 
$0.17 \mathrm{nSv} / \mathrm{Bq} \mathrm{h} \mathrm{m} \mathrm{m}^{-3}$ in equation (8) (UNSCEAR 2000a; Shashikumar et al. 2009).

Dose $=(0.17+9 \times 0.6) C_{R} \times 1760 \times 10^{-6}$

where

$C_{R}=$ is the arithmetic mean radon concentration in $\mathrm{Bq} / \mathrm{m}^{3}$.

\section{Dosimetry of radon progeny / daughters}

The exposure to radon radiation is normally expressed as working level (WL), which is the total energy of a-radiation radiated, when radon and radon progeny reach radioactive equilibrium, provided the radon concentration in the air is $100 \mathrm{pCi} / 1$. In other words, working level is a measure of the concentration of radon progeny, based on the pooled average concentration of radon and can be calculated using the reverse-variance-weighted method for determining the expected exposure to radon in various indoor environments (Bodansky 1989). In the present study, the indoor radon concentration was converted into the equilibrium equivalent concentration (EEC), which was further converted into radon progeny or potential alpha energy concentration (PAEC) using formulae (9) (Shashikumar et al. 2009), (10) (Örgün et al. 2008) or (11) (ICRP 1993a; Upadhyay et al. 2007). Further, the WLM (working level month, WLM/y) is calculated assuming $80 \%$ occupancy, which is equivalent to WL times 40 :

$R_{N}(m W L)=\frac{C_{R} \times F_{R}}{3.7}$

or

$\operatorname{PAEC}(W L)=\frac{A_{C} \times E_{F}}{3700}$

or

$C_{R}(B q / m 3)=\frac{P A E C(W L) \times 3700}{F}$

where

$R_{N}$ or $P A E C=$ radon progeny concentration (WL or $\mathrm{mWL}$ ),

$F_{R}$ or $E_{f}$ or $F=$ the equilibrium factor between indoor radon and radon progeny,

$A_{C}$ or $C_{R}=$ mean concentration of radon gas $\left(\mathrm{Bq} \mathrm{m}^{-3}\right)$.

The annual effective dose due to exposure to radon $\left({ }^{222} \mathrm{Rn}\right)$ and its progeny, and average lifetime fatality risk were determined using generic relations (ICRP 1993b; Sannappa et al. 2003). ICRP assumes $80 \%$ indoor occupancy (7000 h/year) and an indoor equilibrium factor of 0.4 between radon and its decay products for dwellings, the annual exposure at home to radon progeny per unit radon concentration of $1.56 \times 10^{-2} \mathrm{~mJ} \mathrm{~h} \mathrm{~m}^{-3}$ per Bq m $\mathrm{m}^{-3}$ and effective dose per unit exposure at home to radon progeny of $1.1 \mathrm{mSv}\left(\mathrm{mJ} \mathrm{h} \mathrm{m} \mathrm{m}^{-3}\right)$. Under these circumstances, a radon concentration of $1 \mathrm{~Bq} \mathrm{~m}^{-3}$ corresponds to an annual effective dose of $1.716 \times 10^{-2} \mathrm{mSv}$. One WLM corresponds to the exposure of an individual to radon progeny of $1 \mathrm{WL}$ concentration $\left(2.08 \times 10^{-2} \mathrm{~mJ} \mathrm{~m}^{-3}\right)$ for $170 \mathrm{~h}$, which results in $1 \mathrm{WLM}$ being equivalent to $3.54 \mathrm{~mJ} \mathrm{hm}^{-3}$. In a home with a PAEC of $1 \mathrm{mWL}$, the annual exposure in WLM is $(365 \times 24 \times 0.8 / 170 \times 1000)$ $=0.0412 \mathrm{WLM}$. Hence, the dose in terms of working level per month (WLM) can be calculated. The WLM was then converted into annual effective dose by using dose conversion factors: the radon daughter dose conversion factor (ICRP 1993a) for members of the public is $3.88 \mathrm{mSv}$ per WLM $(\sim 3.9 \mathrm{mSV}$ per WLM). The lifetime risk associated with exposure to indoor radon was calculated using $1 \mathrm{WLM}=10 \times 10^{-6}$ cases/year. If the risk persists for 30 years, the lifetime fatality risk is $3 \times 10^{-4}$ cases/ WLM (Nikolaev and Ilic 1999). Hence, the conversion factors of $3 \times 10^{-4}$ per WLM and $3.88 \mathrm{mSv}$ per WLM (ICRP 1993b) were used to estimate the lifetime fatality risk and the annual effective dose, respectively.

\section{Results and discussion}

Temporal variation in the concentration of indoor radon and their respective equivalent dose were obtained using six different methods. The potential alpha energy concentration (PAEC), annual exposure, lifetime fatality risks and annual effective dose due to exposure to radiation from radon progeny are discussed below. Concentration of indoor radon ranged from 1.87 to $14.27 \mathrm{~Bq} / \mathrm{m}^{3}$ of air with an average value of $6.31 \pm 3.2 \mathrm{~Bq} / \mathrm{m}^{3}$ over a period of 24 hours. The mean indoor concentration of radon (and in turn short-lived radon progeny) recorded was considerably less than the action levels prescribed by EPA (i.e., $148 \mathrm{~Bq} / \mathrm{m}^{3}$ ), WHO (i.e., $100 \mathrm{~Bq} / \mathrm{m}^{3}$ ), EEC (i.e., $400 \mathrm{~Bq} / \mathrm{m}^{3}$ ), $\operatorname{ICRP}\left(200-600 \mathrm{~Bq} / \mathrm{m}^{3}\right)$ and NRPB $\left(200 \mathrm{~Bq} / \mathrm{m}^{3}\right)$.

The equilibrium-equivalent concentration of radon $\left(\mathrm{EEC}_{\mathrm{Rn}}\right)$ varied from 0.84 to $6.42 \mathrm{Bqh} / \mathrm{m}^{3}$ with a mean value of $2.84 \pm 1.42 \mathrm{Bqh} / \mathrm{m}^{3}$. The estimate of equivalent dose using Method 1 yielded an effective equivalent dose ranging from 0.074 to $0.562 \mathrm{mSv} / \mathrm{y}$ with an average value of $0.249 \pm 0.125 \mathrm{mSv} / \mathrm{y}$, Method 2 an effective equivalent dose that varied from 0.047 to $0.360 \mathrm{mSv} / \mathrm{y}$, with an average value of $0.159 \pm 0.080 \mathrm{mSv} / \mathrm{y}$, Method 3 an effective equivalent dose that varied from 0.038 to $0.288 \mathrm{mSv} / \mathrm{y}$, with an average value of $0.127 \pm 0.064 \mathrm{mSv} / \mathrm{y}$ and Method 4 an effective equivalent dose that ranged from 0.061 to $0.461 \mathrm{mSv} / \mathrm{y}$, with an average value of $0.204 \pm 0.102 \mathrm{mSv} / \mathrm{y}$. In contrast, Method 5 gave an effective equivalent dose that ranged between 0.094 and $0.713 \mathrm{mSv} / \mathrm{y}$, with an average value of $0.315 \pm 0.158 \mathrm{mSv} / \mathrm{y}$ and Method 6 an effective equivalent dose that ranged between 0.018 and $0.140 \mathrm{mSv} / \mathrm{y}$, with an average value of $0.062 \pm 0.031 \mathrm{mSv} / \mathrm{y}$ (Fig. 2A). It is evident from Fig. 2B that the calculated annual effective equivalent dose due to exposure to indoor 

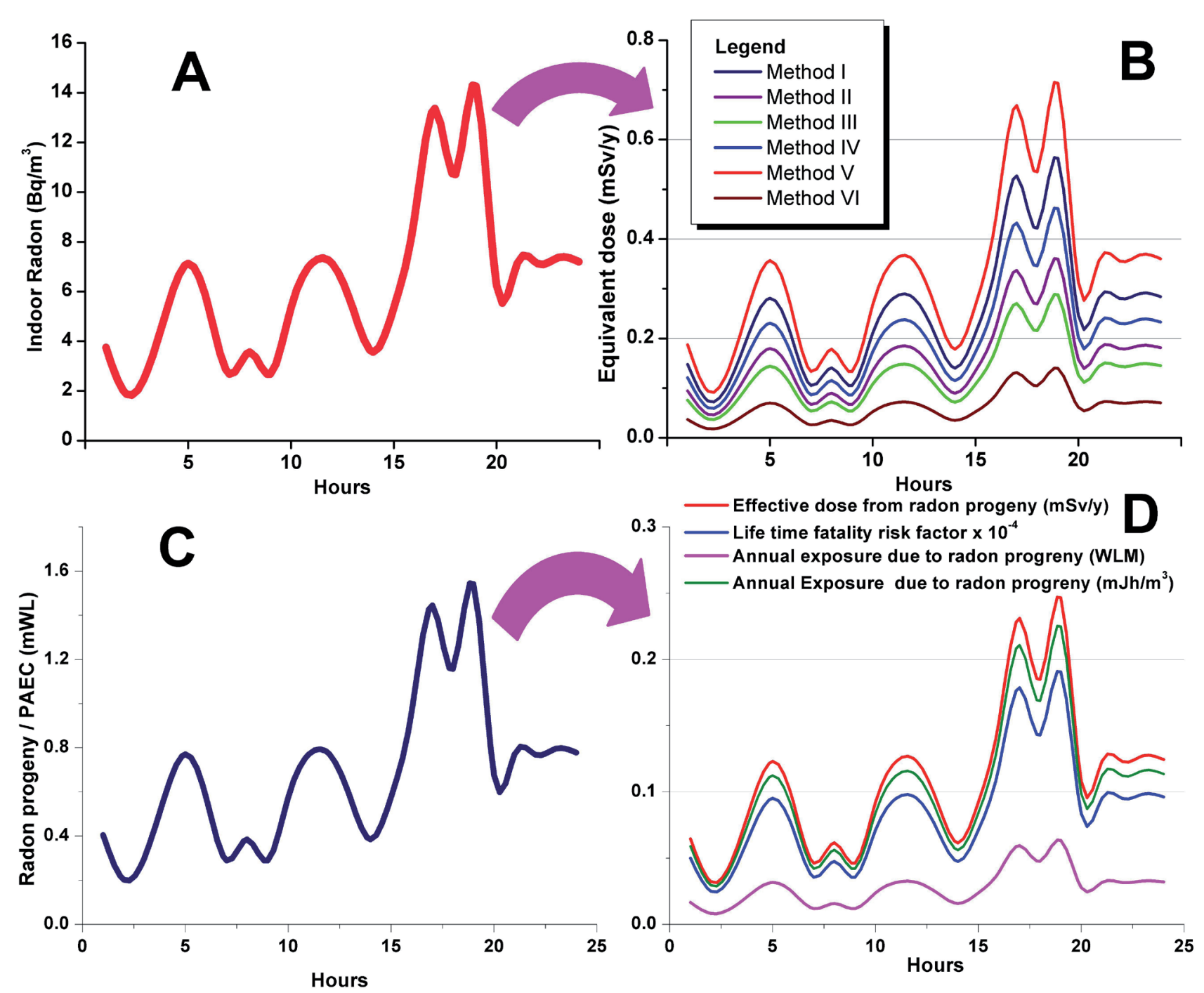

Fig. 2 Temporal variation in (A) the concentration of indoor radon, (B) equivalent dose due to exposure to radon, (C) PAEC or concentration of radon progeny and (D) annual exposure, life time fatality risk and annual effective dose due to exposure to radiation from radon progeny.

radon using all six different methods is below $0.8 \mathrm{mSv} / \mathrm{y}$, which is less than the recommended/estimated global average dose from inhaling radon from all sources, which is approximately $1 \mathrm{mSv} / \mathrm{y}$ (WHO 1993; UNSCEAR 2000b;), and is slightly less than half the total natural exposure to radiation of $2.4 \mathrm{mSv} / \mathrm{y}$ (UNSCEAR 1988). The estimated annual effective equivalent dose corresponding to the concentration of radon measured was also less than the recommended action level of between 3-10 mSv/y (ICRP 1993b).

Results of this comparative account of the concentration of radon indoors and the corresponding equivalent dose of radiation along with the results obtained by other investigators are presented in Table 2. It is evident that the level of radon recorded indoors and the respective equivalent/inhalation doses are within permissible limits and those recorded in the present study are considerably less than those recorded by other investigators in different parts of the world. Choubey and Ramola (1997) state that radon entering through joints and cracks in buildings increases the indoor concentration of radon.
However, in houses/rooms built of brick and cement, the building materials contain very little uranium and coating the floor with cement reduces the entry of radon into the room from the earth's crust. Abd El-Zaher and Fahmi (2008) conclude that the concentration of radon in kitchens and bathrooms is relatively high compared to that in other rooms in the same dwelling and suggest that it can easily be reduced in these rooms by improving the ventilation. Cheol Min Lee et al. (2012) are of the opinion that the concentrations of radon recorded in these rooms are higher than in other indoor environments, where residents tend to spend most time. Although kitchens and bathrooms are constructed mainly of the same building materials (concrete and cement blocks), the materials used for lining these compartments differ from those used in rooms in the same apartment. Kenawy et al. (2000) state that ceramic materials are a potential source of radon, which mainly results from the decay of thorium and uranium in these materials, which are extensively used instead of the traditional painting materials used in living room and bedrooms (Songül and Güler 1999). 
Table 2 A comparison of the concentration of radon and their corresponding equivalent doses recorded indoors on the campus of Bangalore University and those recorded by other investigators in different parts of the world.

\begin{tabular}{|c|c|c|c|c|c|c|c|c|}
\hline \multirow{2}{*}{ Area } & \multicolumn{3}{|c|}{${ }^{222} \mathrm{Rn}$ concentration $\left(\mathrm{Bq} / \mathrm{m}^{3}\right)$} & \multicolumn{4}{|c|}{ Effective Equivalent dose (mSv/y) } & \multirow{2}{*}{ Source } \\
\hline & Min & Max & Mean & Method & Min & Max & Mean & \\
\hline $\begin{array}{l}\text { Bhilangana } \\
\text { Valley, Garhwal Himalaya, India }\end{array}$ & 95 & 208 & - & 1 & 3.8 & 8.1 & - & Choubey and Ramola (1997) \\
\hline Alexandria, Egypt & 50.93 & 105.36 & - & 2 & 1.26 & 2.63 & - & Abd El-Zaher and Fahmi (2008) \\
\hline Dwellings in different areas of Alexandria & 36 & 53 & $44 \pm 16$ & - & 0.61 & 0.9 & 0.75 & Abd-Elzaher (2012) \\
\hline Mashhad, Iran & 12.3 & 135.2 & - & 3 & 0.25 & 3.78 & - & Ali Asghar Mowlavi et al. (2012) \\
\hline Ezine (Çanakkale, Turkey) & 9 & 300 & 67.9 & 3 & 0.4 & 5.2 & - & Örgün et al. (2008) \\
\hline Korea & - & - & $\begin{array}{c}50.17 \pm \\
4.08\end{array}$ & - & - & - & 0.870 & Cheol Min Lee et al. (2012) \\
\hline In a house in Rajshahi, Bangladesh & 3.3 & 37.8 & - & 4 & 0.120 & 1.313 & 0.516 & \multirow{2}{*}{ Farid (1993) } \\
\hline Dwellings in Bangladesh & 8.0 & 46.0 & - & 4 & 0.546 & 1.633 & 1.195 & \\
\hline $\begin{array}{l}\text { Metropolitan } \\
\text { zone of Mexico City }\end{array}$ & $0.1^{*}$ & $32.25^{*}$ & - & 4 & 0.458 & 0.709 & - & Martinez et al. (1998) \\
\hline $\begin{array}{l}\text { Dwellings on the campus of Kuwait } \\
\text { University }\end{array}$ & 8.7 & 23.4 & $\begin{array}{c}14.8 \pm \\
4.6\end{array}$ & 5 & 0.44 & 1.17 & $\begin{array}{c}0.74 \pm \\
0.23\end{array}$ & Maged (2009) \\
\hline Mysore, India & 16.95 & 52.85 & 31.25 & 6 & 0.17 & 0.52 & 0.31 & Shashikumar et al. (2009) \\
\hline Pune & 9.40 & 28.5 & - & 6 & 0.09 & 0.28 & - & Nagaraja et al. (2006) \\
\hline Kastamonu, Turkey & 29 & 177 & - & - & 0.73 & 4.46 & - & Kam and Bozkurt (2007) \\
\hline Campus of Bangalore University & 1.87 & 14.27 & $\begin{array}{l}6.31 \pm \\
3.16\end{array}$ & $\begin{array}{l}1 \\
2 \\
3 \\
4 \\
5 \\
6\end{array}$ & $\begin{array}{l}0.074 \\
0.047 \\
0.038 \\
0.061 \\
0.094 \\
0.018\end{array}$ & $\begin{array}{l}0.562 \\
0.360 \\
0.288 \\
0.461 \\
0.713 \\
0.140\end{array}$ & $\begin{array}{l}0.249 \\
0.159 \\
0.127 \\
0.204 \\
0.315 \\
0.062\end{array}$ & Present study \\
\hline
\end{tabular}

Note: * values in $\mathrm{pCi} / \mathrm{l}$

Another factor determining the high levels of radon and exhalation rates recorded in these compartments is that the narrow openings into these rooms means they are relatively poorly ventilated. Burning natural gas in houses (Karpinska et al. 2004) and supplying kitchens and bathrooms with water from underground sources are both potential sources of indoor radon (Sujo et al. 2004).

The concentration of radon progeny ranged from $0.20 \pm 0.35$ to $1.54 \pm 0.16 \mathrm{mWL}$ (mean: $0.68 \pm 0.34 \mathrm{mWL}$ ) (Fig. 2C). The annual exposure of occupants of dwellings in the study area to radiation from radon daughters varied from $0.030 \mathrm{mJh} \mathrm{m}^{-3}$ (0.008 WLM) to $0.225 \mathrm{mJh} \mathrm{m}^{-3}$ (0.064 WLM) with an average value of $0.099 \mathrm{mJh} \mathrm{m}^{-3}$ (0.028 WLM). The life time fatality risk and annual dose radiation from radon progeny (PAEC) varied from $0.03 \times 10^{-4}$ to $0.19 \times 10^{-4}$ (average: $0.08 \pm 0.04 \times 10^{-4}$ ) and $0.032 \pm 0.056$ to $0.247 \pm 0.026 \mathrm{mSv} / \mathrm{y}$ (mean $0.109 \pm$ $0.055 \mathrm{mSv} / \mathrm{y}$ ), respectively (Fig. 2D). The concentration of radon progeny and monthly level of exposure were considerably less than those reported by Upadhyay et al. (2007), Örgün et al. (2008), Shashikumar et al. (2009), Abd-Elzaher (2012) and Oni et al. (2012), etc. Örgün et al. (2008) records PAEC values of 1.6 to $22.5 \mathrm{mWL}$ and monthly exposure values of 0.1 to $0.9 \mathrm{WLM} \mathrm{y}^{-1}$, while Shashikumar et al., (2009) record concentrations of radon progeny varying from $0.09 \mathrm{mWL}$ to $3.92 \mathrm{mWL}$.
Abd-Elzahfer (2012) reports that the annual exposure of occupants in all areas he studied varied from $0.56 \mathrm{~mJ} \mathrm{~h} \mathrm{~m}^{-3}$ $(0.15 \mathrm{WLM})$ in the region of Elmandara to $0.82 \mathrm{~mJ} \mathrm{~h} \mathrm{~m}^{-3}$ (0.23 WLM) in the region of Kingmaryut. The lifetime fatality risk and the annual effective dose of radiation received by occupants of offices range from $0.86 \times 10^{-5}$ to $1.09 \times 10^{-5}$ and 0.11 to $0.18 \mathrm{mSv} / \mathrm{y}$, respectively (Oni et al. 2012). Upadhyay et al. (2007) record the concentration of radon daughters varying from 0.84 to $6.38 \mathrm{mWL}$, the annual exposure to radiation from radon daughters varying from 0.036 to $0.273 \mathrm{WLM}$, the life time fatality risk varying from $0.11 \times 10^{-4}$ to $0.82 \times 10^{-4}$ and the annual effective dose of radiation from radon (PAEC) varying from 0.14 to $1.06 \mathrm{mSv} / \mathrm{y}$.

\section{Conclusion}

Radon is a naturally occurring, hazardous, radioactive pollutant that is always present in our surroundings and is one of the causes of lung cancer. It is evident that the indoor radon concentrations we recorded are considerably less than those reported by investigators in other parts of the world. Even the risk of a lifetime exposure to indoor radon in the study area is very low and the occupants of these dwellings are therefore, relatively safe. Proper regulatory standards, like natural and forced ven- 
tilation, should be implemented in order to make dwellings more clean and safe. It is also should be kept in mind that only the atmosphere of a single closed staff room was monitored in this study. Therefore, a more extensive survey is required before drawing any definitive conclusions about the general indoor levels of radon and the dosages people are exposed to in buildings on the Bangalore University campus.

\section{Acknowledgements}

Authors are thankful to Board of Research in Nuclear Sciences (BRNS), BARC, Govt. of India, Mumbai.

\section{REFERENCES}

Abd El-Zaher M, Fahmi NM (2008) Studying the Variation of Radon Level in Some Houses in Alexandria City, Egypt. In: IX Radiation Physics and Protection Conference, 15-19 November 2008, Nasr City - Cairo, Egypt, pp. 339-347.

Abd El-Zaher M (2011) Seasonal variation of radon level and radon effective doses in the Catacomb of Kom EI-Shuqafa, Alexandria, Egypt. Pramana. J Phys 77: 749-757.

Abd-Elzaher M (2012) Measurement of indoor radon concentration and assessment of doses in different districts of Alexandria city, Egypt. Environ Geochem Health. doi: 10.1007/s10653 -012-9494-7.

Ali Asghar Mowlavi AA, Maria Rosa Fornasier MR, Ailreza Binesh A, Mario de Denaro M (2012) Indoor radon measurement and effective dose assessment of 150 apartments in Mashhad, Iran, Environ Monit Assess 184: 1085-1088. doi: 10.1007/s10661 -011-2022-x.

Bodansky D (1989) Indoor radon and its hazards. In: Overview of indoor radon problem. University of Washington Press, Seattle and London, pp. 9-23.

CEC (1990) Recommendation de la Commission Relative a la Protection de la Population Contre les Dangers Resultant de l'Exposition au Radon a l'Interieur des Batiments. Brussels: CEC.

Chen J, Moir D (2010) An updated assessment of radon exposure in Canada. Radiat Prot Dosim 140: 166-170. doi:10.1093/rpd /ncq046.

Chen J (2005) A review of radon doses. Radiation Protection Management 22: 27-31.

Choubey VM, Ramola RC (1997) Correlation between geology and radon levels in groundwater, soil and indoor air in Bhilangana Valley, Garhwal Himalaya, India. Environ Geol 32: $258-262$.

EPA (1991) U.S. Environmental Protection Agency - National primary drinking water regulations; radio nuclides; proposed rules. Federal Register: 56, 33050 (www.epa.org).

EPA (1986) US Environmental Protection Agency - A citizen's guide to radon, Office of air and radiation, OPA-86-004.

Faj Z, Planinic J (1991) Dosimetry of Radon and its daughters by two SSNT detectors. Radiat Prot Dosim 35: 265-268.

Farid SM (1993) Equilibrium factor and dosimetry of radon by CR-39 nuclear track detector, Radiat Prot Dosim 50: 57-61.

Farid SM (1995) Passive track detectors for radon determination in the indoor environment. Appl Radiation Isotopes 46: 129-132.
Folger PF, Nyberg P, Wanty RB, Poeter E (1994) Relationship between ${ }^{222} \mathrm{Rn}$ dissolved in groundwater supplies and indoor ${ }^{222} \mathrm{Rn}$ concentrations in some Colorado front-range houses. Health Phys 67: 244-252.

Gillmore GK, Phillips P, Denman A, Sperrin M, Pearce G (2001) Radon levels in abandoned metalliferous mines, Devon, Southwest England. Ecotoxicol Environ Saf 49: 281-292.

IARC (1988) International Agency for Research on Cancer. Summaries and Evaluations Vol. 43 Radon.

ICRP (1987) Lung cancer risk for indoor exposure to radon daughters. (ICRP publications 50) Pergamon Press, Oxford.

ICRP (1990) International Commission of Radiological Protection - Commission recommendation of 21 February 1990 on the protection of the public against indoor exposure to radon (90/143/EURATOM).

ICRP (1993a) Protection against radon-222 at home and at work, Publication 65, Pergamon Press, Oxford.

ICRP (1993b) Protection against Rn-222 at home and at work International Commission on Radiological Protection Publication 65. Ann. ICRP 23 (2). Pergamon Press, Oxford.

ICRP (1994) International Commission on Radiological Protection - protection against radon-222 at home and at work. ICRP Publ., 65. Ann ICRP 23: 1-38. (http://dx.doi.org/10.1016/0146 -6453(93)90002-P).

Karimdoust S, Ardebili L (2010) The environmental impact of radon emitted from hot springs of Sarein (a touristic city north western Iran). World Appl Sci J 10: 930-935.

Karpinska M, Mnich Z, Kapala J (2004) Seasonal changes in radon concentrations in buildings in the region of north-eastern Poland. J Environ Radioact 77: 101-109.

Kenawy MA, Ahmed Morsy A, Abdel Ghany HA (2000) Measurements of radon daughter plate out. Arab J Nucl Sci Appl 34: 79-86.

Kranrod C, Chanyotha S, Chankow N, Tokonami S, Ishikawa T, Sahoo SK (2009) A simple technique for determining the equilibrium equivalent Thoron concentration using a CR-39 detector: Application in mineral treatment industry. Radioprotection 44: 301-304.

Lee SC, Sim IS, Cho YS, Park GY, Kim YS, Goung SJN, Joo YK (2012) Radon Concentrations in Various Indoor Environments and Effective Doses to Inhabitants in Korea. Environment and Pollution 1: 55-68. doi: 10.5539/ep.v1n1p55.

Lubin JA, Boice JD (1997) Lung cancer risk from residential radon: Meta-analysis of eight epidemiological studies. J Nat Cancer Inst 89: 49-57.

Maged AF (2009) Estimating the radon concentration in water and indoor air. Environ Monit Assess 152: 195-201. doi: 10.1007 /s10661-008-0307-5.

Marley F, Denman AR, Philips PS (1998) Studies of radon and radon progeny in air conditioned rooms in hospitals. Radiat Prot Dosim 5: 273-276.

Martinez T, Lartigue J, Navarrete M, Cabrera L, Gonzalez P, Ramirez A, Elizarraras V (1998) Long term and equilibrium factor indoor radon measurements., J Radioana Nucl Chem 236: 231-237.

Mauricio CLP, Tauhata I, Bertelli L (1985) Internal Dosimetry for Radon and radon daughters. Radiat Prot Dosim 11: 249-255.

Nikolaev VA, Ilic R (1999) Etched track radiometers. In radon measurements: a review. Radiat Meas 30: 1-13.

NRC (1999) National Research Council - Committee on the Health Risks of Exposure to Radon (BEIR VI). Health Effects of Exposure to Radon. Committee on the Biological Effects of Ionizing Radiations, Board of Radiation Effects Research, Com- 
mittee on Life Sciences, National Research Council. National Academy Press, Washington, DC.

NRPB (1990) National Radiological Protection Board - Statement by the National Radiological Protection: limitation of human exposure to radon in homes. NRPB Doc 1: 15-16.

Oni OM, Isola GA, Oladapo OO, Oni EA (2012) Estimation of Lifetime Fatality Risk from Indoor Radon in Some Offices in a Nigerian University. Res J Environ Earth Sci 4: 131-133.

Örgün Y, Altınsoy N, Şahin SY, Ataksor B, Çelebi N (2008) A study of indoor radon levels in rural dwellings of Ezine (Çanakkale, Turkey) using solid-state nuclear track detectors. Radiat Prot Dosim 131: 379-384. doi: 10.1093/rpd/ncn190.

Oufni L, Misdaq MA, Amrane M (2005) Radon level and radon effective dose rate determination in Moroccan dwellings using SSNTDs. Radiat Meas 40: 118-123.

Pauloa SR, Neman R, Neto JCH, Iunes PJ, Guedes S, Balan AMOA, Tello CAS (2005) Radon surveys in Brazil using CR-39. Radiat Meas 39: 657-660.

Planinic J, Faj Z (1989) The equilibrium factor between radon and its daughter. Nuclear Instruments and Methods in Physics Research Section A 278: 550-552.

Planinic J, Faj Z (1990) Equilibrium factor and dosimetry by Rn by a Nuclear track detector. Health Phys 59: 349-351.

Reimer GM, Szarzi SL, Been JM (1992) U.S. Geological Survey Open File Report 92-391: 7.

Sannappa J, Chandrashekaara MS, Satish LA et al. (2003) Study of background radiation dose in Mysore city, Karnataka State, India. Radiat Meas 37: 55-65.

Shashikumar TS, Ragini N, Chandrashekara MS, Paramesh L (2009) Radon in soil and its concentration in the atmosphere around Mysore city, India. Indian J Phys 83: 1163-1169.

Sohrabi M (1998) The state of the art on worldwide studies in some environments with elevated naturally occurring radioactive materials (NORM). Appl Radiat Isot 49: 169-188.

Somlai K, Tokonami S, Ishikawa T, Vancsura P, Gáspár M, Jobbágy V, Somlai J, Kovács T (2007) ${ }^{222} \mathrm{Rn}$ concentration of water in the Balaton Highland and in the southern part of Hungary, and the assessment of the resulting dose. Radiat Meas 42: 491-495.
Songül A, Vaizolu SA, Güler Çaatay (1999) Indoor Radon Concentrations in Ankara Dwellings. Indoor and Built Environment 8: $327-331$.

Srivastava A (2004) An overview of an indoor radon study carried out in dwellings in India and Bangladesh during the last decade using solid state nuclear track detectors. J Environ Radioact 78: 113-121.

Sujo L, Colmenero Sujo L, Montero Cabrera ME, Villalba L, Renteria Villalobos M, Torres Moye E, Garcia Leon M, Garcia-Tenorio R, Mireles Garcia F, Herrera Peraza Sanchez Aroche D (2004) Uranium-238 and thorium-232 series concentrations in soil, radon-222 indoor and drinking water concentrations and dose assessment in the city of Aldama, Chihuahua, Mexico. J Environ Radioact 77: 205-219.

UNSCEAR (1988) United Nations Scientific Committee on the Effects of Atomic Radiation - Sources, effects and risks of ionizing radiation. Report to the General Assembly, with annexes. United Nations. New York.

UNSCEAR (1999) United Nations Scientific Committee on the Effect of Atomic Radiation. United Nations. New York.

UNSCEAR (2000a) Report to the General Assembly with Scientific Annexes, United Nations, Annexure-B 97.

UNSCEAR (2000b) United Nations Scientific Committee on the Effects of Atomic Radiation - Report to the General Assembly. New York, United Nations.

Upadhyay SB, Kant K, Rekha Joshi, Sonkawade RG, Chakarvarti SK, Sharma GS (2007) Radon-thoron and their progeny dosimetry in the environment of LPG bottling plant using plastic track detectors. Ind J Pure Appl Phys 45: 880-883.

WHO (1988) World Health Organization - Indoor Air Quality: Radon report of a WHO working group. J Environ Sci 8: 73-91.

WHO (1993) World Health Organization - Guidelines for drinking water quality (vol. 1, 2nd ed.). Geneva: WHO Recommendations.

WHO (2005) World Health Organization Radon and cancer. Fact Sheet No. 291 (June 2005). (available at http://www.who.int /mediacentre/factsheets/fs291/en/index.html).

WHO (2009) World Health Organization - Sets radon action level of 2.7 - less lung cancer risk than EPA 4.0. Global Press Release Distribution (www.PRLog.org). 